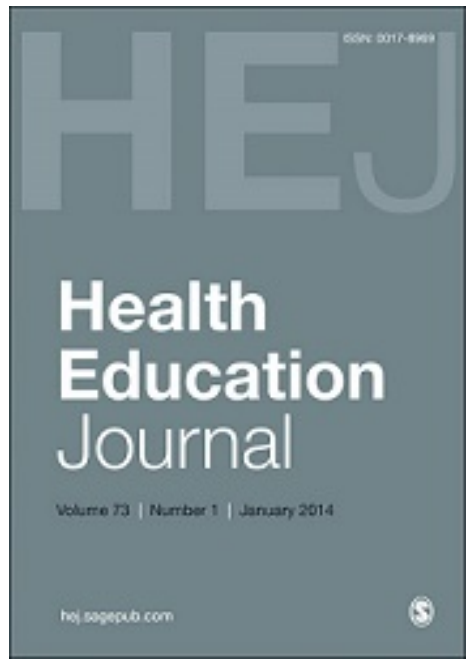

\title{
Emotions and Professional Reflections in a Post-War Community: Teachers' perspectives from Kosovo
}

\begin{tabular}{|c|l|}
\hline Journal: & Health Education Journal \\
\hline Manuscript ID & HEJ-19-0397.R3 \\
\hline Keyworcript Type: & Short Reports \\
\hline Keywe & $\begin{array}{l}\text { Reflective teachers, reflective thinking, teachers' emotions, post war } \\
\text { community, trauma, Kosovo }\end{array}$ \\
\hline Bbstract: & $\begin{array}{l}\text { Background: Teaching is more complex than dealing with the cognitive } \\
\text { aspects of learning alone and is also influenced by affective states. } \\
\text { Because of this, more research is needed into the role of teachers' } \\
\text { emotions in classroom interaction. Of special importance is research into } \\
\text { reflective thinking and the extent to which it may be disturbed by the } \\
\text { prior experience of trauma. } \\
\text { Purpose: This study aimed to shed light on these issues by analysing } \\
\text { reports of Kosovan teachers' emotional arousal when speaking about } \\
\text { and/or teaching topics related to war experiences, their beliefs about } \\
\text { these experiences, their opinions about students' reactions, and their } \\
\text { reports on professional reflective practices. } \\
\text { Methods: A descriptive study. Data were collected by means of a } \\
\text { structured questionnaire completed by 70 teachers. } \\
\text { Results: Teachers reported strong emotions were triggered by } \\
\text { discussion of topics linked to the war. Their beliefs influence how they } \\
\text { engage with sensitive and emotionally charged topics, but they interpret } \\
\text { their professional behaviour through reflective and critical thinking. } \\
\text { Conclusions: Both external and internal factors affect post-war teachers } \\
\text { cognitively and emotionally. Further investigation is needed to identify } \\
\text { the extent to which this impacts on teachers' impact on the ability to use } \\
\text { critical reflection and critical emotional reflexivity in school-based } \\
\text { practice. }\end{array}$ \\
\hline
\end{tabular}




\section{SCHOLARONE" Manuscripts}




\title{
SHORT REPORT
}

\section{Emotions and Professional Reflections in a Post-War Community: Teachers' perspectives from Kosovo}

Edona Berisha Kida a and Cathal Butler ${ }^{b}$

a Department of Primary Education, Faculty of Education, University of Pristine, Kosovo

${ }^{b}$ School of Education and English Language, University of Bedfordshire, United Kingdom

\begin{abstract}
Background: Teaching is more complex than dealing with the cognitive aspects of learning alone and is also influenced by affective states. Because of this, more research is needed into the role of teachers' emotions in classroom interaction. Of special importance is research into reflective thinking and the extent to which it may be disturbed by the prior experience of trauma.

Purpose: This study aimed to shed light on these issues by analysing reports of Kosovan teachers' emotional arousal when speaking about and/or teaching topics related to war experiences, their beliefs about these experiences, their opinions about students' reactions, and their reports on professional reflective practices.

Methods: A descriptive study. Data were collected by means of a structured questionnaire completed by 70 teachers.

Results: Teachers reported strong emotions were triggered by discussion of topics linked to the war. Their beliefs influence how they engage with sensitive and emotionally charged topics, but they interpret their professional behaviour through reflective and critical thinking.

Conclusions: Both external and internal factors affect post-war teachers cognitively and emotionally. Further investigation is needed to identify the extent to which this impacts on teachers' impact on the ability to use critical reflection and critical emotional reflexivity in schoolbased practice.
\end{abstract}

Keywords: Teachers, reflection, reflective thinking, emotions, post-war, trauma, Kosovo.

\section{Corresponding author:}

Edona Berisha Kida, Faculty of Education, University of Pristine, St. Bedri Pejani, H2, No 30, Bresje, Fushe Kosove, 11000, Kosovo

Email: edona.berisha-kida@uni-pr.edu 


\section{Introduction}

\section{Teachers' emotions}

Emotions have a crucial role to play in everyday life, influencing communication and engagement (Kleinginna and Kleinginna, 1981). While studies have addressed emotion from different perspectives, teachers' emotions had not been much researched until the last decade (Fried et al., 2015). Importantly, emotions inform classroom dynamics and are expressed through teacher-student and student-student interaction (Hosotani and Imai-Matsumura, 2011). Kelchtermans (2009), in his literature review of teachers' emotions, emphasises how emotions should be acknowledged as an integral part of educational processes. Teachers' emotions are closely linked to their commitment to the job, and aspects of professionalism (Kelchtermans, 2009).

Informed by recent research, Fried et al. (2015) developed a theoretical framework to describe teachers' emotions. In addition to interpersonal and intrapersonal factors, social, cultural, and political influences were identified as influencing the development of teachers' emotions (Fried et al., 2015). Emotions serve as a powerful vehicle for enhancing or inhibiting learning (Greenleaf, 2002), and teachers' conscious or unconscious emotional expression is affected by their individual goals, expectations and experiences (Sutton, 2007). Consequently, it is not enough for teachers to only have academic knowledge and good teaching skills; it is also important for them to have the emotional understanding and skills needed to work effectively with students (Prosen et al., 2011).

According to research that documents the importance of teachers' emotions in teaching, teachers' self-awareness should be increased. In order to respond properly in complex situations, they first must be aware of their own feelings and internal and/or external contributing factors. To assist in this, the cognitive process of reflection may be used to enhance awareness (Šarić, 2015).

\section{Reflection and reflective teachers}

Studies of the cognitive processes involved in learning are older than those focusing on the emotional aspects, dating back at least to the $19^{\text {th }}$ century. The way experiences may be used to enhance learning was explored in the book How We Think by the educational philosopher, John Dewey (1933). Dewey stated that since life itself is an educational process, people learn from their everyday experiences, so the learning process should be made more explicit. According to Dewey, the aims of curriculum-based learning are achieved only when students are able to apply in everyday life what they have learned at school. To facilitate this happening, Dewey proposed the notion of reflective thought, or the metacognitive process of active, persistent, and careful consideration of knowledge and its structure (Burrows, 2012; Sünbül and Kurnaz, 2016).

Later schools of thought developed the concepts of reflection, reflective thinking and reflective learning as part of their work. In general, reflection is a cognitive process that seeks to analyse actual and previous knowledge, enabling new productive understandings to be developed from experience and then applied in pursuit of change. Thus, reflection in 
educational settings is a higher order cognitive process that can help teachers gain insight from their working experiences to rethink aspects of professional practice (Fullan, 1993). Reflective thinking skills enable teachers to sustain learning throughout their careers and become creative in problem-solving activities (Sünbül and Kurnaz, 2016). However, teachers often lack practice in the application of reflection to their professional work, as the teaching process and their interactions with students become automated (Choy and Oo, 2012). Automated responses arise through an unconscious filtering that mediates our responses to certain external events. This filtering is based on past experience, beliefs, assumptions and expectations, emotions, and personal agendas and aspirations (Manrique and Abchi, 2015).

If teachers do not address the unconscious dynamics that inform their possible reactions, they run the risk of responding to students inappropriately, which may negatively impact on learning and relationship development. Thus, so as not to allow unconscious dynamics compromise professional success, teachers must develop reflective thinking, continually check the components of their personal filtering systems, and avoid automated responses in educational settings (Manrique and Abchi, 2015).

\section{Teachers' emotions and reflective thinking}

Teachers' reflection on their emotions is linked to classroom pedagogy (Zembylas, 2002). Cognitive, educational and personality development theory signals how the affective state of a caring adult has an effect on children's development (Demetriou and Wilson, 2008). When thinking upon the development of a relationship to stimulate students' emotional and cognitive functioning in educational settings, we should first consider whether the dynamics of studentteacher interaction are well suited to provide such stimulation. Given that teachers' emotions are influenced by contextual factors, interpersonal, intrapersonal, social, cultural, and political influences may interfere and reduce the ability to use critical and reflective thinking to affect personal and emotional reactions in the classroom.

In post-war countries such as Kosovo, it is important to identify the personal and sociocultural factors that influence teachers' core beliefs and emotional engagement in school. What factors influence them to act emotionally in one way or another? How deep seated are these influences? How can teachers be helped to understand and engage with these factors to do their best professionally and stimulate their students' development? These are questions that await scientific answers. A recent research literature showing that successful teaching and learning is the result of the integration of emotion and cognition encourages us to focus on both of these factors in order to create healthy and supportive teaching environments (Demetriou and Wilson, 2008). However, clinical data show that emotional and cognitive dynamics can be deeply affected by the experience of trauma, especially in countries affected by conflict and war.

\section{Reflection and severe traumatic experiences}

Research has shown that secure attachment to caregivers has a crucial role to play in the development of emotional awareness (Lanius et al., 2011). But what is the ability of teachers to reflect and help new generations when they themselves have been involved in traumatic 
situations? The clinical literature highlights how trauma affects interpersonal relationships through fearfulness, an extreme need for control, the internalisation of aggressive models, and in other ways. (Hyde, 1996). In these situations, children and students may not secure a stable attachment to a "nurturing" adult in the form of a caregiver or teacher. Furthermore, recent neuro-psychological studies have shown that in individuals suffering from Post-Traumatic Stress Disorder there may be a deactivation of neural networks associated with self-reflection, emotional regulation and social cognition (Bluhm et al., 2012; Olsson et al., 2015). Researchers have asked whether these deficits affect the ability to give proper care to new generations. If so, it may facilitate the transmission of intergenerational trauma (Olsson et al., 2015).

Following the 9/11 terrorist attacks on the World Trade Buildings in New York, researchers started to explore reflection as a cognitive process and the role of teachers, educational institutions and the community in enhancing trauma resilience (Moss and Nichols, 2002). In clinical settings, the importance of self-reflection in the treatment of traumatised individuals can be witnessed in the growth of cognitive behavioural and cognitive processing therapies (Lanius et al., 2011). Self-reflection seems to aid the treatment process by increasing emotional self-awareness and the regulation of affective states. Teachers who have experienced trauma may benefit from psychological support to help them address emotional/psychological needs and advance their reflective skills. This may help in personal healing from trauma, prevent trauma transmission through the education system and create a sound, safe and successful professional interaction with students.

Informed by such ideas, the work of Bound, Keogh, and Walker (1985) on reflection as be a valid way of learning, and the concept of critical emotional reflexivity as developed by Zembylas (2014), this study sought to investigate teachers' emotions and professional reflection in Kosovo as a post-war community.

\section{Study aims}

Towards the end of the 1990s, Kosovo experienced extensive atrocities as the result of a war waged on an ethnic basis. Inflicting psycho-emotional injuries at a personal and cultural/societal level, the war left communities and institutions to confront many difficulties. The Kosovo education system in particular was badly damaged. According to UNICEF (2004), around $45 \%$ of schools were completely destroyed. Since then, the education system has undergone a number of transitional reforms. As part of these, efforts have been made to support teachers' professional development although there are claims that this support was not as fulsome as it should have been (Berisha Kida, 2019; Murphy and Hamer, 2014; Sommers and Buckland, 2004). In particular, teachers have lacked institutional support to overcome their own trauma-related difficulties, develop reflective skills and help new generations in this regard. In a recent study, $40 \%$ of teachers from a sample of 200 met the cut-off criteria for Post-Traumatic Stress Disorder (Berisha Kida, 2018, 2019). Within this context, the present study sough to address the following questions.

- Do teachers show an emotional response when they teach topics directly or indirectly related to their war trauma experiences?

- Do teachers share similar beliefs on sensitive topics, and their interpretation? 
- Do teachers use reflection as a means to increase their emotional awareness and understand the impact of their emotions on classroom dynamics?

- Have teachers noticed that students have prior knowledge of war trauma experiences?

- Are students emotionally involved in discussion of topics that directly or indirectly relate to recent war trauma experiences?

To answer these questions, the study aimed to collect data on teachers' emotional responses to discussion of war/trauma related topics, reveal their beliefs about these topics, and amass data on their reflective practices. Their opinions about students' previous knowledge and reactions to war trauma experiences were also documented.

\section{Methods}

\section{Design, procedure and ethical considerations}

This study is a descriptive one. An official request to approach school staff was approved by the Kosovo Ministry of Education, Science and Technology (MEST) in May, 2018 (protocol number 2436/2437). The study adhered to the American Psychological Association's (APA) Ethical Principles and Code of Conduct (APA, 2010). In line with these principles, teacher participants were informed about the aims and procedures of the study and were assured of confidentiality and anonymity.

Most participants were accessed through the Programi për avancim të kualifikimit të mësimdhënësve-AKM" - an in-service teacher education programme run by the Faculty of Education at Pristine University. Individual meetings were held with teachers in the programme to ascertain their availability and willingness to participate. In total, 100 teachers were contacted, with 70 of them responding to the questionnaire.

The sample included teachers from six Kosovan municipalities - 25 from Pristine, 15 from Peja, 10 from Mitrovica, 10 from Gjilani, 6 from Gjakova, and 4 from Fushe-Kosova. The sample comprised 58 women and 12 men, reflecting the fact there are more women than men in the Kosovo education system (Mekolli et al., 2016). The age of participants varied from 30 to 58 years old.

\section{Instruments}

Data were collected by means of a two-part instrument. The first part used a Likert-scale to assess subjective responses concerning teachers' emotional state when addressing topics associated with war-related experiences. Other questions collected information on teachers' beliefs regarding the pedagogical aspects of engaging with such sensitive topics and whether they perceived their students to have prior knowledge on the topics.

The second part of the instrument assessed teachers' reflective thinking and was adopted from the Teachers Reflective Questionnaire-TRQ developed by Choy and Oo, (2012). The questionnaire covers four major areas of reflective functioning: the ability to self-assess, awareness of how one learns, the development of lifelong learning skills, and the influence of 
beliefs about self and self-efficacy. It comprised 33 items, each scored on a Likert scale. The adaptation of the questionnaire followed standard procedure. The questionnaire's authors' permission was received, then it went through translation and back translation prior to adaptation to the study aims. The Albanian version contains 24 items in total. The instrument's reliability as measured by Cronbach's alpha was acceptable $(\alpha=.71)$.

\section{Data analysis}

Data analysis was conducted using SPSS 20. Results from the first part of the questionnaire were analysed descriptively. Responses to the second part of the questionnaire were analysed in relation to three levels of teacher reflection: introductory, intermediate and advanced. The first of these levels indicated that the teacher rarely reflected on his or her practice; the second that the teacher sometimes reflected on his/her teaching practice, but not very deeply; while the third meant that the teacher reflected deeply on his or her teaching practice and was constantly making efforts to improve it.

\section{Results}

Overall, study findings indicate that teachers' emotions were significantly influenced by experience of the war, and that teachers' beliefs influenced the way in which they dealt with sensitive and/or emotionally charged topics. Beyond this, teachers reported that students had prior knowledge of issues relating to the war. Many teachers reported an interest to further developing their professional practice through a reflective and critical thinking lens.

\section{Emotional responses when teaching topics that relate to war trauma experiences}

Overall, $69 \%$ of the teachers reported emotional upset when dealing with sensitive content relating to the war. Settings in which such content might be encountered included (a) when teaching about certain events in the history subject curriculum; b) when addressing human rights issues as part of social studies subjects; c) when teaching literature using poems expressing feelings of war loss, grief and/or victory; and d) on special occasions such as celebrations or national holidays. Only a very small number of teachers (around 1\%) reported that the emotional disturbance was so great as to inhibit their ability to continue teaching.

\section{Beliefs related to trauma-sensitive topics}

In addition to asking about emotional responses to sensitive topics, items in the first part of the data collection schedule sought teachers' views on war topics and the way these topics should be talked about. 14\% of teachers shared the belief that "history deserves to be taught [about] and discussed emotionally", 33\% agreed with the option "Our history is worth to be taught [about] emotionally/with pride", $42 \%$ chose the option "We shall never forget our past", and $11 \%$ chose "We should carefully present historical facts". Overall, there was some reported improvement in teachers' emotionality with respect to discussion of these issues over time (Table 1) 
[Table 1 about here]

\section{Students' prior knowledge of war and involvement in classroom discussion}

When asked whether students had knowledge of war-related topics, $41 \%$ of teachers answered that students had a lot of such knowledge, $51 \%$ said that students had some knowledge, and $8 \%$ indicated that students did not have previous knowledge of these issues. Regarding whether students became involved emotionally in classroom discussion of sensitive topics associated with war and trauma, $82 \%$ of teachers said "yes" and only $18 \%$ said "no."

\section{Teachers' reflective practices}

[Table 2 about here]

With respect to the second part of the questionnaire, teachers largely provided responses commensurate with the higher levels of reflection. Teachers assigned themselves a mean score of 2.78 (out of 5) with respect to looking for areas of connectivity between what they taught and their own life experiences. They also strongly believed (a mean score of 4.27) that "I know that in a lesson there are many areas, like content and context that can make or break a lesson" With respect to items addressing awareness of how learning takes place, teachers scored highly in response to the following statements:

- "Students learn very differently from when I was in school, I need to look to new strategies to better deliver my lessons so that I can remain relevant now as well as in the future" (a mean score of 3.47 ).

- "I try to reflect on what I do during my lessons so that I can strengthen the strategies I use with new and more effective ones" (a mean score of 3.95).

- "I know I have my strengths and weaknesses and teaching is a difficult job to carry out. I need constantly to examine my practice in order to be more effective in my lessons" (a mean score of 3.49).

Finally, teachers highly agreed about the influence of beliefs on the teaching process. Responses to the item "I know that what I believe about myself and others will ultimately control my behaviour" resulted with a mean score of 4.30 .

\section{Discussion}

Findings indicate that the majority of teachers experience emotional arousal when addressing war related sensitive topics in their teaching. Results from the belief item scores indicate that teachers' beliefs are heavily influenced by socio-political dynamics. Before the war in Kosovo, the education system had functioned as a tool of resistance against Serbian repression operating as a political tool and parallel system disconnected from the Serbian-imposed curriculum. Within it, teachers were important figures of political resistance promoting cultural 
and ethnic identification (Berisha Kida, 2019; Sommers and Buckland, 2004), and teachers still see this as part of their role in relation, for example, to the teaching of history.

Furthermore, results point to students' prior knowledge of war and emotional involvement in classroom discussions. It is clear therefore that community experiences of war has been transferred to the new generations. In Bosnia and Hercegovina, the main sources of information about war atrocities among the younger generation are reported as adults, including parents, grandparents and teachers; the media; and schools, via curriculum areas such as history, religion, politics and personal development (Magill et al., 2009). Since the mid1990s attention is being paid to the role of schools in post-conflict societies, how schools may have contributed to and/or continue to contribute to identity-based conflicts (Magill et al., 2009; Weinstein et al., 2007).

Modern psycho-pedagogical approaches claim for enhancement of psycho-pedagogical skills focused on preventing trauma transmission, stereotyping, stigmatisation, and exclusion through teaching especially social studies' subjects. Particularly, they support the theory that critical thinking and an interactive classroom mediated by a reflective teacher might contribute to the building of a tolerant and pluralistic society (Berisha Kida, 2019; 2018; Weinstein et al., 2007; Sommers and Buckland, 2004). Whether this is possible for teachers who report that teaching about such topics as their history evokes strong emotions is perhaps questionable. It is quite possible that teachers' responses to discussion about recent history are automated and their reflective abilities remain locked within a personal filtering system influenced by core beliefs and the affective domain (Fried et al., 2015; Manrique and Abchi, 2015).

\section{Do teachers use reflection as a cognitive tool to increase emotional awareness?}

Data in this study identified that a majority of teachers were advanced in terms of their level of professional reflection. They claimed a readiness to change teaching strategies if needed. What was less clear, however, was the extent to which they could be flexible when teaching about emotionally charged issues, particularly those identified within this research.

Teachers in this study noted their reflectiveness tended to be restricted to professional issues such as teaching and learning as cognitive processes. This can be explained by responses to the two parts of the questionnaire. The first part addressing personal experiences triggered numerous emotional reactions, while the second part of the questionnaire (adopted from the Reflective Teacher Questionnaire) assessed teachers' reflections of their everyday teaching. Importantly teachers agreed that content, context, personal beliefs and self-efficiency had a major influence on the teaching process. Extended training to enhance the skills to encourage reflection on personal feelings (i.e. to develop critical emotional reflexivity) and the impact of these feelings on teaching and learning is needed in post-war/trauma affected communities.

Studies have found statistically important correlations between perceived teachers' emotions and students' own emotions of joy, anger and anxiety (Berisha Kida and Karaj, 2019; Šarić, 2015). This implies further research into teacher identity as a subjective and professional practice on the one hand and on teachers' professional knowledge on the other. The study evidences the need for a more integrated approach to addressing reflection on the impacts of cognitive and emotional processes in education. 


\section{Study limitations}

Study limitations include the opportunistic nature of the sample, who was recruited through the researchers' institution. While the sample size is large, the nature of the sample, being drawn from those involved in inservice training raises questions about generalisability. A questionnaire, while advantageous in collecting data from a large sample, does not allow for the depth of data which could illuminate the extent to which teachers are able to step back and reflect on teaching about emotive subjects, and how they might go about doing this work in the classroom.

\section{Conclusion}

Findings concerning Kosovo teachers' emotional reactions, beliefs and reflective practices and their views about students' prior knowledge and involvement in the discussion of certain sensitive topics, suggest that war-related trauma experiences influence classroom dynamics. There is evidence that deep rooted socially constructed beliefs influence the teaching process, and that teachers use reflection more as a tool for thinking about pedagogy, learning and cognitive processes than as a means for personal and social change in learning and development.

\section{References}

APA (2010) Ethical Principles of Psychologists and Code of Conduct. Available at: http://www.apa.org/ethics/code/principles.pdf

Ball A and Lardner T (1997) Disposition Toward Literacy: Constructs of Teacher Knowledge and the Ann Arbor black English case. College Composition and Communication 48(4): 469485.

Berisha Kida E (2019) Trauma dhe transmetimi i saj. Pristine: Zero Print. Available at: https://www.researchgate.net/publication/336994745 Trauma psikologjike dhe trans metimi i saj Monografi shkencore

Berisha Kida E and Karaj T (2019) Development of an Albanian version of the Questionnaire on Teacher-Student Interaction. Center for Educational Policy Studies Journal. Epub ahead of print. https://doi.org/10.26529/cepsj.45

Berisha Kida E (2018) Hulumtimi i lidhjeve në mes të çrregullimit të stresit pas traumës dhe mbështetjes sociale te veteranët, 14 vite pas luftës në Kosovë. Tirane: Thesis defended at University of Tirana. doi:10.13140/RG.2.2.29271.93607 Available at: https://www.researchgate.net/publication/331982384 Hulumtimi i lidhjeve ne mes te crregullimit te stresit pas traumes dhe mbeshtetjes sociale te veteranet 14 vit e pas luftes ne Kosove Psikologji e traumes dhe trans-traumes ne Kosove

Burrows NL (2012) Reflective thinking by teachers and improvement in teaching practices. PhD thesis, Oklahoma State University. Available at: https://pdfs.semanticscholar.org/9cd5/46172085d2edf7cc2d2ce9c3381cd76a0fc0.pdf 
Bluhm RL, Frewen PA, Coupland NC, Densmore M, Schore AN and Lanius RA (2012) Neural correlates of self-reflection in post-traumatic stress disorder. Acta Psychiatrica Scandinavica 125(3): 238-246.

Choy ChS and Oo SP (2012) Reflective thinking and teaching practices: A precursor for incorporating critical thinking into the classroom? International Journal of Instruction 5(1): 167-182

Demetriou $\mathrm{H}$ and Wilson $\mathrm{E}$ (2008). A return to the use of emotion and reflection. Teach\&Learn 21(11): 938-941.

Dewey J (1933) How We Think: A Restatement of the Relation of Reflective Thinking to the Educative Process. Boston: Houghton Mifflin.

Fried L, Mansfield C and Dobozy E (2015) Teacher emotion research: Introducing a conceptual model to guide future research. Issues in Educational Research 25(4): 415-440.

Fullan M (1993) Change Forces: Probing the Depths of Educational Reform. London: Falmer Press; Levittown, PA, Falmer Press.

Greenleaf RK (2002) The adolescent brain: Still ready to learn. Principal Leadership 2(8): 24-25. Hosotani R and Imai-Matsumura K (2011) Emotional experience, expression, and regulation of high-quality Japanese elementary school teachers. Teaching and Teacher Education 27(6) 1039-1048.

Hyde RW (1996) Transference and Countertransference and the Trauma Triangle: Ethics. Houston Texas: The Houston Galveston Trauma Insitute.

Kelchtermans G (2009) Who I am in how I teach is the message: Self-understanding, vulnerability and reflection. Teachers and Teaching: Theory and Practice 15(2): 257-272.

Kleinginna PR and Kleinginna AM (1981) A categorized list of emotion definitions, with suggestions for a consensual definition. Motivation and Emotion 5(4): 345-379.

Lanius RA, Bluhm LR and Frewen PA (2011) How understanding the neurobiology of complex post traumatic stress can inform clinical practice: A social cognitive and afective neuroscience approach. Acta Psychiatrica Scandinavica 124(5): 331-348.

Manrique SM and Abchi SV (2015) Teachers' practices and mental models: Transformation through reflection on action. Australian Journal of Teacher Education 40(6): 13-33.

Magill C, Smith A and Hamber B (2009) The Role of Education in Reconciliation: The Perspectives of Children and Young People in Bosnia and Herzegovina and Northern Ireland. Belfast: UNESCO Centre, University of Ulster.

Mekolli E, Bruqi Sh, Lahi H, Rexhepi N, Fazliu M, Radoni S and Cakolli A.(2016) Statistikat e Arsimit në Kosovë 2015/2017. Prishtinë: ASK.

Moss $G$ and Nichols J (2002) Reflective practitioner preparation: In the wake of 21st century terrorism. Current Issues on Education 5: 1-16.

Murphy C (1989) Freud in the writing center: The psychoanalytic of tutoring well. Writing Center Journal 10(1): 13-18.

Murphy R and Hamer J (2014) Situational Analysis of School Education in Kosovo. Manchester, UK: AlphaPlus Consultancy Ltd.

Olsson A, Kross E, Nordberg S, Weinberg A, Weber J, Schmer-Galunder S, Fossella J, Wager DT, Bonanno AG and Ochsner NK (2015) Neural and genetic markers of vulnerability to posttraumatic stress symptoms among survivors of the World Trade Center attacks. Social Cognitive and Affective Neuroscience 10: 863-868. 
Prosen S, Smrtnik Vitulic H and Poljsak Skraban O (2011) Teachers' emotional expression in interaction with students of different ages. Center for Educational Policy Studies Journal 1(3): 141-157.

Šarić M (2015) Teachers' emotions: A research review from a psychological perspective. Journal of Contemporary Educational Studies, 66: 10-26.

Sommers M and Buckland P (2004) Parallel Worlds: Rebuilding the Education System in Kosovo. Paris: IIEP-UNESCO.

Sünbül AM and Kurnaz D (2016) Reflective thinking and teaching reflective thinking. In: Akdemir AS, Kaya Z, and Ataş Akdemir Ö, (eds) Learning and Teaching: Theories, Approaches and Models. Ankara: Gozom, pp. 167-173.

Sutton RE (2007) Teachers' anger, frustration, and self-regulation. In: Schutz P and Pedrun R (eds) Emotion in Education. Amsterdam: Elsevier Academic Press, pp. 259-274.

UNICEF (2004) Puna e femijeve ne Kosove. New York: UNICEF.

Weinstein HM, Freedman SW and Hughson H. (2007) School Voices: Challenges Facing Education Systems after Identity-Based Conflicts. Education, Citizenship and Social Justice 2(1): 4171.

Wolpow R, Johnson M, Hertel R and Kincaid S (2016) The Heart of Learning and Teaching: Compassion, Resiliency, and Academic Success. Washington: OSPI.

Zembylas M (2002) Constructing genealogies of teachers' emotions in science teaching. Journal of Research in Science Teaching 39: 79-103.

Zembylas M (2003) Interrogating 'Teacher Identity': emotion, resistance, and self-formation, Educational Theory 53(1): 107-127.

Zembylas M (2014) The place of emotion in teacher reflection: Elias, Foucault and "critical emotional reflexivity." Power and Education 6(2): 210-222. 


\section{Table 1. Questionnaire responses}

How do you feel when you discuss something in your class related to war experience?

\begin{tabular}{|l|l|}
\hline General Responses & $\%$ \\
\hline $\begin{array}{l}\text { Since I have experienced the war, I notice myself having } \\
\text { emotional arousal, but I continue the discussion }\end{array}$ & 69 \\
\hline No I don't have any reactions & 14 \\
\hline $\begin{array}{l}\text { Immediately after the war, it was worse, but now I can } \\
\text { [more] easily manage these discussions }\end{array}$ & 16 \\
\hline I feel so bad that I try to finish discussion immediately & 1 \\
\hline
\end{tabular}

Table 2. Multiple response analyses for three levels of professional reflection

\begin{tabular}{|c|c|c|}
\hline Advanced & Intermediate & Introductory \\
\hline $61 \%$ & $49.7 \%$ & $24 \%$ \\
\hline
\end{tabular}

